\title{
PENGARUH MODEL PEMBELAJARAN PROCESS ORIENTED GUIDED INQUIRY LEARNING (POGIL) TERHADAP KEMAMPUAN KOMUNIKASI SISWA PADA SUBKONSEP URINARIA KELAS XI DI MA
}

\author{
Aditya Rahman ${ }^{1}$ \\ Meliyana $^{2}$ \\ Ika Rifqiawati $^{3}$ \\ 1,2,3) Jurusan Pendidikan Biologi FKIP Universitas Sultan Ageng Tirtayasa \\ E-mail: ${ }^{1}$ Adityauntirta@gmail.com, ${ }^{2}$ meli.yana21@yahoo.com, ${ }^{3}$ ikarifqiawati@untirta.ac.id

\begin{abstract}
This research aimed to observe the influence of learning model Process Oriented Guided Inquiry Learning (POGIL) type towards students communication ability (written and oral) of urinary subconcept class XI. The method used quasiexperiment with randomize control group only research design. This research was held in MA class XI 2nd-semester academic year of 2017/2018. The sampling technique used in this research was random sampling with class XI IPA 3 as experiment class which Process Oriented Guided Inquiry Learning (POGIL) was implemented and class XI IPA 4 as control class. Students' written communication ability on experiment class with good category $(71,4 \%)$, control class with enough category $(58,67 \%)$ and students oral communication on experiment class with good category $(68,67 \%)$ and on control class with enough category $(59,1 \%)$. The result of hypothesis test analysis by using $Z$ test on significant level $\alpha=0.05$, significance value result was $(0.000)<0.05$ Ho rejected for written communication ability and significance value result was $(0.002)<0.05$ Ho rejected for oral communication ability, therefore it can be concluded that there was influence of learning model Process Oriented Guided Inquiry Learning (POGIL) towards communication ability (oral and written) of urinary subconcept class XI in MA.
\end{abstract}

Keywords: communication ability, Process Oriented Guided Inquiry Learning (POGIL), students oral communication

Pembelajaran dalam implementasi kurikulum 2013 yaitu pembelajaran yang beriorientasi pada peserta didik (student center) sedangkan guru berperan sebagai fasilitator di dalam proses pembelajaran. Peran guru sebagai fasilitator berfungsi untuk membangkitkan rasa ingin tahu peserta didik, sehingga akan terjadi proses belajar yang kreatif, inovatif, dan menyenangkan secara berkelanjutan (Mulyasa, 2015: 48).

\begin{abstract}
Proses pembelajaran dengan melibatkan siswa merupakan hal yang penting karena dengan demikian siswa mendapatkan pengalaman belajar secara langsung, sehingga siswa akan mudah mengingat apa yang telah didapatkan dari proses pembelajaran yang telah dilakukan.

Keberhasilan

proses pembelajaran dapat tercapai jika terjadi interaksi antara guru dengan siswa, ataupun siswa dengan siswa yang saling bekerjasama secara
\end{abstract}


harmonis. Keaktifan dalam kegiatan pembelajaran tidak hanya guru yang mendominasi, akan tetapi siswa juga ikut berperan aktif dalam kegiatan pembelajaran. Menurut Yusup (2009: 18) pendidikan merupakan proses yang melibatkan unsur seperti pendidik, administrator pendidikan, proses, komunikasi, peserta didik dan informasi pendidikan serta adanya tujuantujuan yang ingin dicapai dari proses pendidikan yang dimaksud. Oleh karena itu, komunikasi sangat diperlukan di dalam proses pembelajaran untuk mencapai tujuan pembelajaran.

Berdasarkan hasil wawancara dengan guru biologi kelas XI di MA, kegiatan siswa di kelas khususnya mata pelajaran biologi yaitu siswa hanya mengandalkan siswa yang aktif saja ketika melakukan kegiatan diskusi dan kurangnya kerjasama dalam proses diskusi tersebut. Ketika proses pembelajaran guru cenderung menggunakan metode konvensional (ceramah) sedangkan siswa hanya mencatat penjelasan guru dan mendengarkan informasi serta mengerjakan soal-soal yang diberikan oleh guru, Sehingga siswa cenderung pasif dalam proses pembelajaran. Berdasarkan hasil angket siswa, Salah satu penyebab siswa yang cenderung pasif dalam pembelajaran ialah kesulitan dalam komunikasi secara lisan ataupun tulisan. Adapun kesulitan secara lisan diantaranya siswa tidak terbiasa dalam mengajukan pendapat dan mengajukan pertanyaan ketika proses pembelajaran berlangsung dikarenakan siswa kurang percaya diri terhadap pertanyaan atau pendapat yang akan mereka sampaikan. Sedangkan kesulitan komunikasi secara tulisan berdasarkan hasil angket respon siswa menjelaskan bahwa siswa belum pernah mengerjakan soal analisis dalam bentuk penyajian tabel, grafik ataupun diagram karena siswa cenderung menghafal konsep dalam mengerjakan soal-soal yang diberikan oleh guru.

Keikutsertaaan siswa secara aktif di dalam proses pembelajaran diharapkan mampu untuk mengembangkan kemampuan siswa mengkomunikasikan hasil pembelajaran yang dilakukannya. Salah satu model pembelajaran yang mampu meningkatkan komunikasi siswa yaitu model pembelajaran Process Oriented Guided Inquiry Learning (POGIL) yang merupakan model pembelajaran yang berbasis penemuan (Hanson, 2006: 3). Model pembelajaran Process Oriented Guided Inquiry Learning (POGIL) merupakan model yang berorientasi pada peserta didik (Student Center) adapun proses belajar dengan model ini dilakukan secara kelompok melalui kegiatan inkuiri terbimbing dan pertanyaan yang digunakan untuk meningkatkan kemampuan berpikir kritis, menyelesaikan masalah, melaporkan, metakognisi, dan tanggung jawab individu. 
Subkonsep urinaria yaitu bagian dari materi sistem eksresi yang merupakan salah satu materi dalam pelajaran biologi kelas XI di MA. Subkonsep urinaria dibahas tentang proses terbentuknya urin sampai kelainan yang dapat terjadi pada sistem urinaria. Berdasarkan penelitian Cholistiana (2014: 4) menyatakan bahwa banyaknya konsep yang harus dipahami dan dikuasai oleh siswa membuat siswa mengalami kesulitan dalam memahami materi tersebut. Selain itu, subkonsep urinaria banyak membahas mengenai proses yang terjadi di dalam tubuh sehingga siswa tidak dapat mengamati secara langsung, maka dalam penyampaiannya akan terasa membosankan jika hanya menggunakan metode ceramah.

Berdasarkan latar belakang tersebut, maka perlu dilakukan suatu penelitian dengan judul "Pengaruh model pembelajaran Process Oriented Guided Inquiry Learning (POGIL) terhadap kemampuan komunikasi siswa pada sukonsep urinaria kelas XI di MA”.

\section{METODE}

Penelitian ini dilaksanakan di MA tahun pelajaran 2017/2018 pada kelas XI. Adapun waktu penelitian dilaksanakan pada semester genap tanggal 16-21 April 2018. Metode penelitian yang digunakan adalah metode kuasi eksperimen dan desain penelitian ini mengunakan Randomized control group only. Populasi pada penelitian ini adalah seluruh siswa kelas XI IPA di MA tahun ajaran 2017/2018 yang berjumlah 4 kelas. Teknik pengambilan sampel penelitian ini menggunakan teknik random sampling dengan sampel yang digunakan adalah kelas XI IPA 3 sebagai kelas eksperimen dan kelas XI IPA 4 sebagai kelas kontrol.

Instrumen yang digunakan dalam penelitian ini berupa soal uraian berjumlah 6 soal dengan tujuan untuk mengukur kemampuan komunikasi tulisan, sedangkan Instrumen yang digunakan mengukur kemampuan berkomunikasi secara lisan berupa lembar observasi.

\section{HASIL DAN PEMBAHASAN}

\section{A. Kemampuan Komunikasi Tulisan \\ Kemampuan komunikasi tulisan} siswa diukur dengan menggunakan soal uraian, adapun hasil persentase rata-rata nilai posttest kemampuan komunikasi tulisan siswa kelas eksperimen dan kelas kontrol dapat dilihat pada Gambar 1.

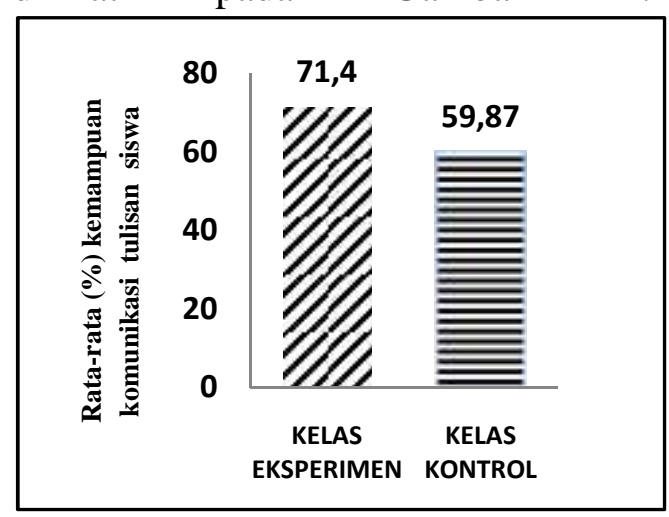

Gambar 1 Persentase rata-rata nilai komunikasi tulisan siswa

Berdasarkan Gambar 1, Rata-rata persentase komunikasi tulisan siswa 
didapatkan dengan dilakukan posttest dan diperoleh nilai kelas eksperimen lebih tinggi dibandingkan dengan kelas kontrol. Rata-rata persentase pada kelas eksperimen yaitu $71,4 \%$ dengan kategori baik, sedangkan kelas kontrol yaitu 59,87 \% dengan kategori cukup. Hal tersebut dikarenakan pada saat proses pembelajaran pada kelas eksperimen menggunakan model pembelajaran Process Oriented Guided Inquiry Learning (POGIL), siswa diberikan kesempatan untuk melatih kemampuan komunikasi tulisannya.

Setelah didapatkan rata-rata nilai kemampuan komunikasi tulisan, selanjutnya dilakukan uji hipotesis (Uji-Z) menggunakan SPSS versi 20, sebelumnya dilakukan uji prasyarat terlebih dahulu yaitu uji normalitas dan uji homogenitas. Didapatkan hasil uji normalitas pada kelas eksperimen sig. $0,140>0,05$ yang berarti data berdistribusi normal dan pada kelas kontrol sig. 0,057 yang berarti data kemampuan komunikasi tulisan berdistribusi normal. Pada uji homogenitas diperoleh nilai sig. 0,393 $>0,05$ yang berarti data bersifat homogen. Setelah hasil yang didapatkan data berdistribusi normal dan bersifat homogen, lalu dilakukan uji prasyarat yaitu uji $\mathrm{Z}$ dengan sig. (2-tailed) $0,000<0,05$ yang artinya Ho ditolak dan $\mathrm{H}_{1}$ diterima. Dapat disimpulkan bahwa terdapat pengaruh model pembelajaran Process
Oriented Guided Inquiry Learning (POGIL) terhadap kemampuan komunikasi tulisan siswa pada subkonsep urinaria kelas XI di MA.

Proses pembelajaran dengan menggunakan model pembelajaran Process Oriented Guided Inquiry Learning (POGIL) ini yang menjadi pengaruh terhadap kemampuan komunikasi tulisan siswa yaitu terdapat pada tahap ke 1 dan tahap ke 3 yaitu tahap eksplorasi (Explore) dan tahap aplikasi konsep (Concept application).

Pada tahap eksplorasi (Explore), siswa dapat melatih kemampuan komunikasi tulisannya dengan cara siswa dapat menuliskan hasil pengamatan hasil praktikum ke dalam bentuk tabel. Ketika siswa melakukan uji kandungan amonia pada urin, siswa dituntut untuk menuliskan hasil pengamatannya ke dalam bentuk tabel terkait warna urin sebelum dipanaskan dan sesudah dipanaskan. Sedangkan pada tahap aplikasi konsep (Concept application), siswa dituntut untuk mengerjakan soal-soal HOTS dengan disajikannya suatu pertanyaan yang dikaitkan dengan indikator kemampuan komunikasi tulisan di dalamnya. Adapun rekapitulasi rata-rata kemampuan aspek komunikasi tulisan siswa setiap indikator pada kelas eksperimen dan kelas kontrol, dapat dilihat pada Gambar 2. 


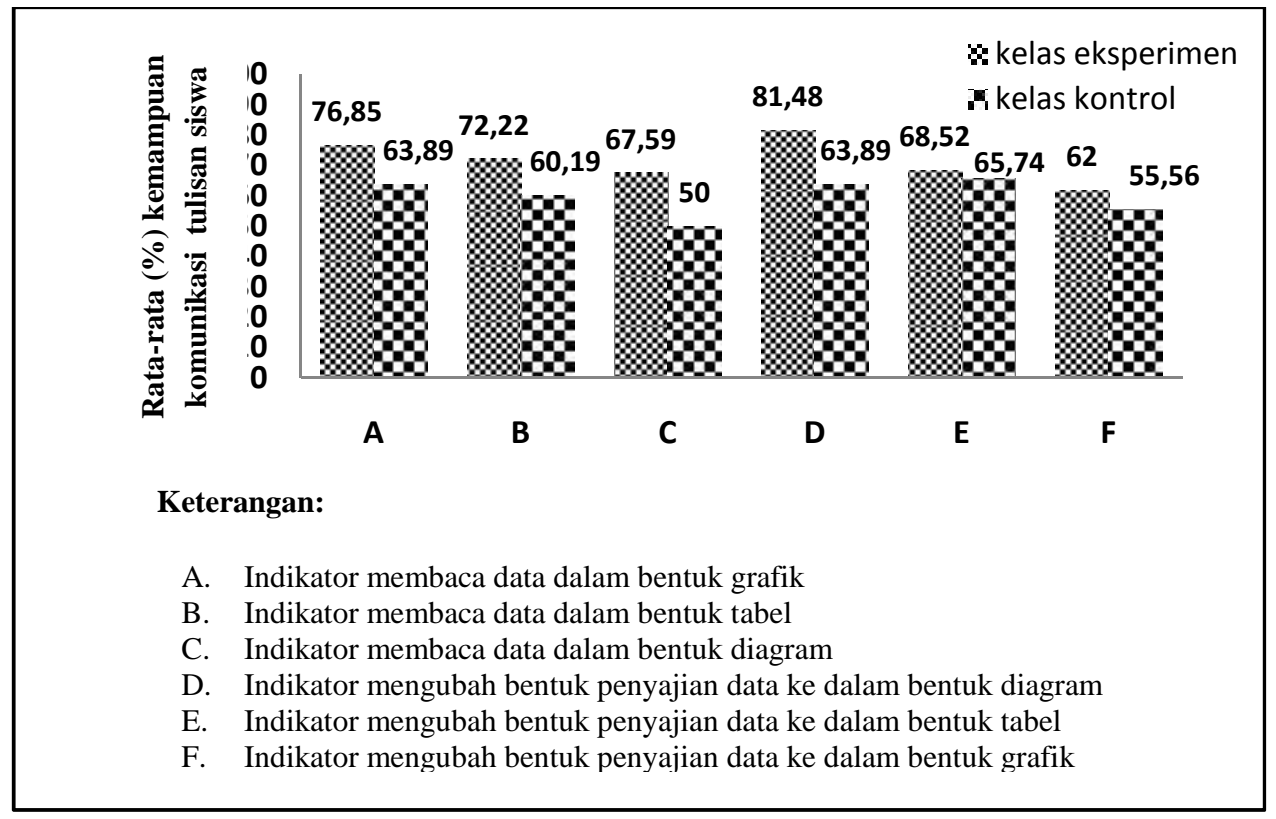

Gambar 2. Rekapitulasi rata-rata kemampuan aspek komunikasi tulisan siswa setiap indikator pada kelas eksperimen dan kelas kontrol

\section{a. Indikator Membaca Data}

Berdasarkan Gambar 2, menunjukkan bahwa nilai rata-rata tertinggi pada indikator membaca data, nilai rata-rata posstest tertinggi pada kelas eksperimen terdapat pada indikator membaca data dalam bentuk grafik dengan perolehan nilai rata-rata sebesar 76,85\% dengan kategori baik, sedangkan pada kelas kontrol yaitu 63,89\% dengan kategori cukup. Hal ini disebabkan karena pada tahap concept application siswa dituntut untuk memahami bentuk soal dengan indikator membaca data yang disajikan dalam bentuk grafik yang disajikan di LKS pada pertemuan 1, sehingga siswa dapat mengerjakan soal posttest dengan baik, karena siswa sudah mempunyai pengalaman dalam mengerjakan soal tersebut. Menurut penelitian Subali dkk (2015: 1-2) menyatakan bahwa pada era informasi ini kemampuan memahami grafik bagi siswa sangat penting. Karena data yang disajikan dengan grafik menjadi lebih mudah dipahami bila dibanding data yang disajikan dalam bentuk kalimat uraian. Grafik adalah jenis representasi yang berguna dalam merangkum data, mengolah dan menafsirkan informasi baru dari data yang kompleks. Namun pada kelas kontrol, kemampuan dalam membaca data dalam bentuk grafik kurang dilatihkan dalam proses pembelajaran, sehingga siswa tidak mempunyai pengalaman dalam mengerjakan soal tersebut dan ketika menjawab soal posttest banyak siswa yang masih kurang tepat dalam menjawab soal sesuai arahan soal.

Indikator membaca data dalam bentuk diagram merupakan rata-rata persentase yang terendah pada indikator membaca data dibandingkan dengan indikator lainnya. Didapatkan nilai rata-rata persentase kelas 
eksperimen yaitu 67,59 \% dengan kategori baik, sedangkan pada kelas kontrol yaitu $50 \%$ dengan kategori kurang. Hal ini disebabkan karena baik pada kelas eksperimen dan kontrol siswa kurang dilatihkan membaca data dalam bentuk diagram dalam proses pembelajaran di LKS, sehingga menyebabkan siswa dalam mengisi soal kurang sesuai arahan soal yang telah ditentukan dan kurang tepatnya siswa untuk mencocokan data yang disajikan berdasarkan keterangan variabel $\mathrm{x}$ dan y.

Menurut Subali dkk (2015: 1) menyatakan bahwa bentuk penyajian dalam bentuk diagram atau grafik sering dianggap sebagai perangkat matematika, karena berkomunikasi melalui representasi grafik ataupun diagram membutuhkan kompetensi matematika seperti, persepsi visual, berpikir logis, ploting data, memprediksi gerakan garis, mendeduksi hubungan antara variabel.

\section{b. Indikator Mengubah Bentuk Penyajian Data}

Nilai rata-rata tertinggi pada indikator mengubah bentuk penyajian data yaitu terdapat pada indikator mengubah bentuk penyajian data dalam bentuk diagram pada kelas eksperimen dengan nilai rata-rata tertinggi yaitu $81,48 \%$ dengan kategori baik sekali, dibandingkan dengan indikator yang lain. hal ini disebabkan karena saat melakukan kegiatan diskusi pada pertemuan ke 2 disajikan LKS yang terdapat tahap concept application yang menuntut siswa untuk menganalisis suatu artikel tentang penyebab terjadinya gagal ginjal, dimana siswa dituntut untuk membuat suatu diagram batang sesuai persentase penyebab gangguan gagal ginjal pada artikel tersebut. Hal tersebut sesuai dengan penelitian Khasanah (2016: 2) yang menyatakan bahwa kegiatan pembelajaran harus dapat disajikan sebagai suatu proses penemuan dan terkait dengan pengalaman peserta didik, sehingga pengetahuan yang diperoleh bersifat lama, dapat diingat, dan mampu meningkatkan penalaran siswa dan dapat meningkatkan karakter siswa.

Pada kelas kontrol indikator dalam mengubah bentuk penyajian data dalam diagram dengan nilai ratarata 63,89\% dengan kategori cukup, hal ini dikarenakan pada kelas kontrol kemampuan dalam mengubah bentuk penyajian data kedalam bentuk diagram kurang dilatihkan dalam proses pembelajaran di LKS dan ketika menjawab soal posstest banyak siswa yang masih kurang tepat untuk menentukan variabel $\mathrm{x}$ dan $\mathrm{y}$ pada soal. Menurut penelitian Kurnia dan Suryowati (2014: 4) menyatakan bahwa diagram berfungsi sebagai alat untuk mengkomunikasikan dan mengklasifikasikan data, dengan menggunakan diagram siswa dapat membandingkan data dan menampilkan hubungan matematis yang seringkali tidak dapat ditampilkan oleh representasi yang lain. Oleh karena itu, pembiasaan siswa dalam mengerjakan bentuk penyajian data dalam bentuk diagram di dalam proses pembelajaran 
merupakan hal yang penting untuk melatih siswa dalam mengkomunikasikan dan mengklasifikasikan data.

Nilai rata-rata terendah terdapat pada indikator mengubah bentuk penyajian data dalam bentuk grafik pada kelas eksperimen yaitu $62 \%$ dengan kategori cukup dan pada kelas kontrol yaitu 55,56 \% dengan kategori cukup. Hal ini disebabkan karena baik pada kelas eksperimen dan kontrol siswa disajikan soal posttest, dimana siswa tidak langsung diberikan data untuk membuat keterangan pada variabel $\mathrm{x}$ dan $\mathrm{y}$ akan tetapi siswa harus menganalisis data terlebih dahulu untuk melengkapi isi tabel pada soal tersebut, sehingga menyebabkan siswa menuliskan ketidaklengkapan pada keterangan variabel $\mathrm{x}$ dan $\mathrm{y}$. Disebabkan juga karena siswa kurang dilatihkan dalam proses pembelajaran mengerjakan soal-soal bentuk penyajian grafik. Adapun menurut penelitian Subali dkk (2015: 2) menyatakan bahwa kemampuan interpretasi grafik merupakan salah satu kemampuan yang sulit bagi siswa di sekolah, hal ini karena kemampuan tersebut berkaitan dengan kemampuan ruang (spatial), kemampuan logika dan kemampuan matematika. Agar kemampuan interpretasi grafik baik, maka ketiga kemampuan (ruang, logika dan matematika) harus optimal dikuasai oleh siswa.

\section{A. Kemampuan Komunikasi Lisan}

Kemampuan komunikasi lisan siswa diukur mengunakan lembar observasi, Adapun hasil persentase rata-rata nilai kemampuan komunikasi lisan siswa kelas eksperimen dan kelas kontrol dapat dilihat pada Gambar 3.

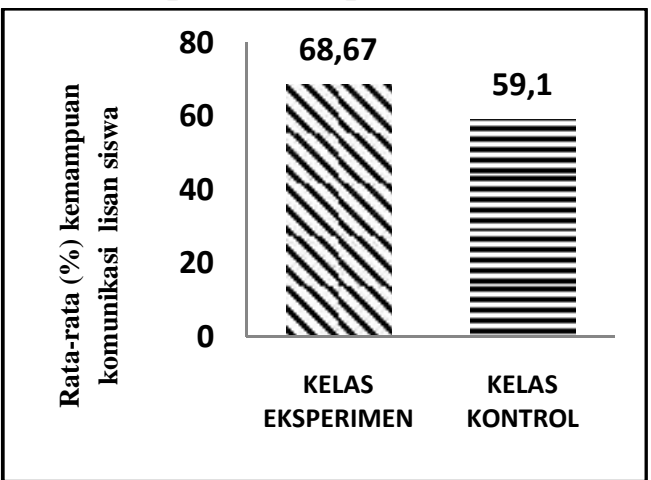

Gambar 3. Persentase rata-rata nilai komunikasi lisan siswa

Berdasarkan Gambar 3 rata-rata persentase komunikasi lisan siswa yang dinilai menggunakan lembar observasi selama kegiatan diskusi dan presentasi. Hasil yang diperoleh yaitu nilai kelas eksperimen lebih tinggi dibandingkan dengan kelas kontrol. Hal ini dikarenakan adanya tahapan dalam model pembelajaran Process Oriented Guided Inquiry Learning (POGIL) yang memberikan kesempatan kepada setiap siswa untuk melatih kemampuan komunikasi lisan dengan adanya kegiatan praktikum pada tahapan explore. Adapun berdasarkan Arikunto (2012: 281), menggolongkan rata-rata kemampuan komunikasi lisan pada kelas eksperimen memiliki kategori baik dengan jumlah 68,67 \% sedangkan kelas kontrol yaitu 59,1 \% dengan kategori cukup.

Setelah didapatkan rata-rata nilai kemampuan komunikasi lisan, selanjutnya dilakukan uji hipotesis (Uji-Z) menggunakan SPSS versi 20, sebelumnya dilakukan uji prasyarat 
terlebih dahulu yaitu uji normalitas dan uji homogenitas. Didapatkan hasil uji normalitas pada kelas eksperimen yaitu signifikan 0,194 > 0,05 yang berarti data berdistribusi normal, dan pada kelas kontrol signifikan $0,160>0,05$ yang berarti data kemampuan komunikasi lisan berdistribusi normal. Pada uji homogenitas diperoleh nilai signifikan $0,703>0,05$ berarti data bersifat homogen. Setelah hasil yang didapatkan data berdistribusi normal dan bersifat homogen, lalu dilakukan uji prasyarat yaitu uji $\mathrm{Z}$ dengan signifikan (2-tailed) $0,002<0,05$ yang artinya $\mathrm{Ho}$ ditolak dan $\mathrm{H}_{1}$ diterima. Dapat disimpulkan bahwa terdapat pengaruh model pembelajaran Process Oriented Guided Inquiry Learning (POGIL) terhadap kemampuan komunikasi lisan siswa pada subkonsep urinaria kelas XI di MA.

Proses pembelajaran dengan menggunakan model pembelajaran Process Oriented Guided Inquiry Learning (POGIL) ini yang menjadi pengaruh terhadap kemampuan komunikasi lisan siswa yaitu terdapat pada tahap ke 1 yaitu tahap eksplorasi (Explore) dan saat kegiatan presentasi. Pada tahapan explore, siswa dapat berperan aktif dalam melakukan kegiatan praktikum yang dilakukan pada masing-masing kelompok. Hal tersebut memberikan kesempatan kepada siswa untuk melatih kemampuan komunikasi lisan dengan cara setiap siswa dapat memberikan pendapat terhadap perubahan warna pada larutan uji kandungan urin yang dihasilkannya.

Menurut penelitian Fujiarti \& Mastur (2014: 5) menyatakan bahwa pembelajaran dengan menggunakan model POGIL, pada tahap eksplorasi akan terjadi elaborasi kognitif yang baik. Sehingga dapat meningkatkan daya nalar, keterlibatan siswa dalam pembelajaran dan memberi kesempatan pada siswa untuk mengungkapkan pendapat serta sanggahan terkait hasil percobaan yang telah dilakukan oleh siswa. Pembagian anggota kelompok secara merata yaitu siswa yang memiliki akademik tinggi dapat membantu siswa yang memiliki akademik rendah dalam memahami suatu konsep.

Saat kegiatan diskusi berlangsung, siswa dapat berperan aktif antara sesama anggota kelompoknya. Sehingga dalam kelas eksperimen seluruh siswa ikut berperan aktif di dalam praktikum dan diskusi. Hal ini diperkuat dengan pendapat Ningsih dkk (2015: 3) bahwa model pembelajaran POGIL didasarkan pada prinsip kontruktivisme yang dapat memicu siswa belajar aktif melalui interaktif dalam kelompok untuk memecahkan masalah. Sehingga melalui penggunaan model pembelajaran siswa mampu untuk mengembangkan keterampilan, berpikir tingkat tinggi, metakognisi, komunikasi, kerja tim, manajeman dan penilaian (Hanson, 2006: 5). Adapun rekapitulasi ratarata kemampuan aspek komunikasi lisan siswa setiap indikator pada kelas 
eksperimen dan kelas kontrol, dapat dilihat pada Gambar 4.

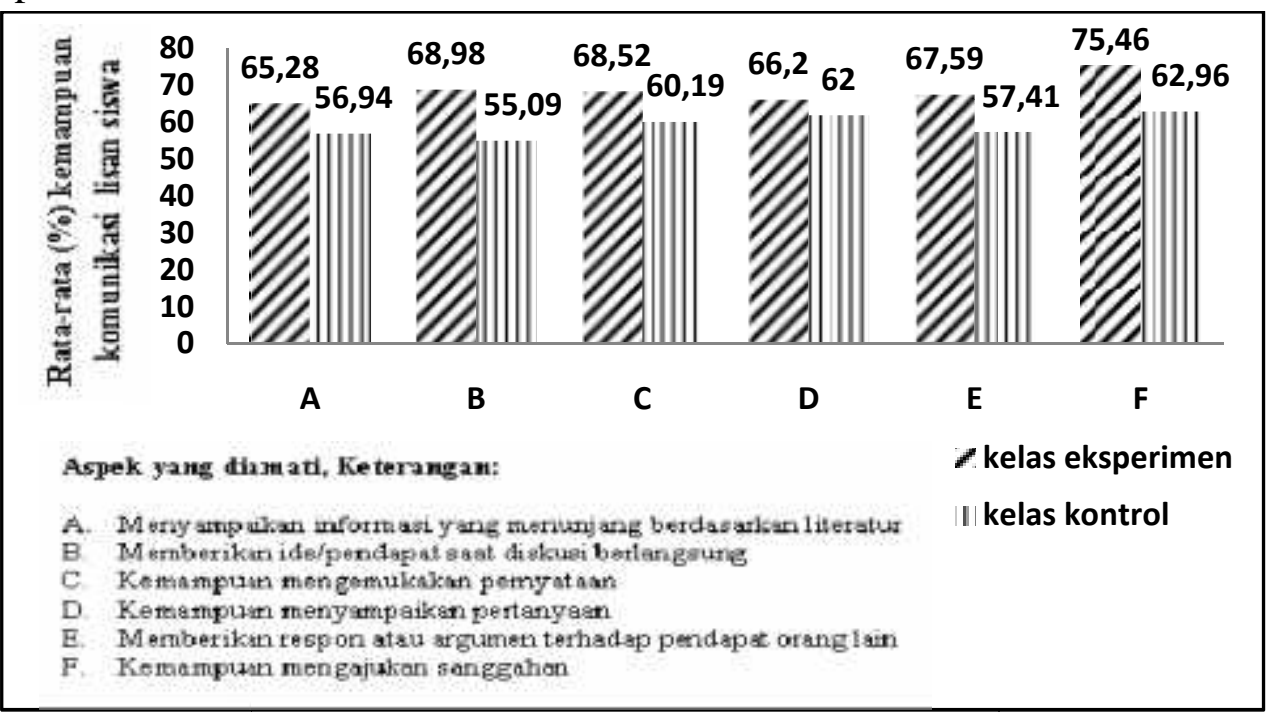

Gambar 4. Rekapitulasi rata-rata kemunculan aspek kemampuan komunikasi lisan siswa pada kelas eksperimen dan kontrol

Berdasarkan Gambar 4, rata-rata kemunculan aspek kemampuan komunikasi lisan siswa pada kelas eksperimen dan kelas kontrol tertinggi pada aspek kemampuan mengajukan sanggahan yang memperoleh nilai $75,46 \%$ dengan kategori baik pada kelas eksperimen, sedangkan pada kelas kontrol memperoleh nilai rata-rata persentase yaitu $62,96 \%$ dengan kategori cukup. Hal ini dikarenakan, setelah tahapan aplikasi konsep (Concept application) yaitu dilakukannya kegiatan presentasi dimana siswa pada kelas eksperimen aktif mengajukan sanggahan dan masing-masing siswa diberikan kesempatan untuk mengajukan sanggahan untuk menanggapi hasil percobaan yang dilakukan oleh kelompok lain. Siswa cenderung mengajukan sanggahan terkait hasil warna pada larutan uji kandungan urin saat kegiatan praktikum yang dilaksanakan pada masing-masing kelompok dengan hasil yang berbeda-beda dengan kelompok lainnya. Adapun menurut Lafenasti dkk (2018 :3) Pembelajaran praktikum memberi kesempatan bagi peserta didik untuk menemukan dan membuktikan teori. Dengan begitu, pembelajaran praktikum dapat menunjang pemahaman peserta didik terhadap materi pelajaran. Adapun dalam kegiatan percobaan dapat terjadi jika hasil dari suatu percobaan tidak sesuai dengan teori yang ada, hal tersebut dapat disebabkan karena faktor dari praktikan yang saat melakukan suatu percobaan tidak sesuai dengan cara kerja yang telah ditentukan. Dapat diperjelas dari pernyataan Ginanjar dkk (2015: 2) yang menyatakan bahwa sanggahan adalah adanya argumen-argumen yang berbeda. 
Pada kelas kontrol, ketika guru memberikan waktu untuk melakukan kesempatan tanya-jawab saat kegiatan presentasi cenderung siswa masih kurang percaya diri dalam mengungkapkan sanggahan dan terdapat yang memberikan sanggahannya akan tetapi dalam penyampaiannya belum sistematis yang seharusnya sesuai dengan subyek, predikat, obyek dan keterangan (SPOK).

Pada indikator menyampaikan informasi yang menunjang berdasarkan literatur merupakan ratarata persentase yang terendah dibandingkan dengan indikator lainnya. Didapatkan nilai rata-rata persentase pada kelas eksperimen sebesar 65,28 \% dengan kategori baik dan untuk kelas kontrol sebesar 56,94 $\%$ dengan kategori cukup. Persentase kelas eksperimen lebih tinggi dari pada kelas kontrol dikarenakan pada tahap penemuan konsep (explain), siswa dituntut untuk mengerjakan soal-soal yang disajikan di LKS yang berhubungan pada hasil praktikum yang telah dilakukan dan konsep urinaria.

Rendahnya rata-rata persentase pada indikator menyampaikan informasi yang menunjang berdasarkan literatur baik pada kelas eksperimen dan kontrol disebabkan karena siswa yang mencari informasi dengan menggunakan buku paket atau searcing di internet hanya satu atau dua orang siswa saja, siswa saling mengandalkan siswa yang lain untuk mencari informasi. Sebelum siswa menyampaikan informasi yang menunjang berdasarkan literatur hendaknya siswa dituntut terlebih dahulu membaca buku atau mencari sumber-sumber yang terdapat di internet, proses membaca inilah yang menjadi hambatan siswa dalam mencari informasi. Karena berdasarkan penelitian Natalia et al (2016: 5) menyatakan bahwa rendahnya minat membaca siswa hal tersebut disebabkan karena siswa menganggap bahwa membaca buku merupakan hal yang membosankan, sehingga siswa lebih tertarik untuk melakukan aktifitas lain.

Saat menyampaikan informasi, siswa cenderung tidak sistematis dalam menyampaikan informasi yang disampaikannya, sehingga teman sekelompoknya tidak memperhatikan temannya yang sedang berbicara, sehingga informasi yang disampaikan tidak didapatkan oleh seluruh anggota kelompok. Sumiati dan Asri (2009: 67) menyatakan bahwa komunikasi berarti berpartisipasi, memberitahukan, dan menjadikan informasi yang disampaikan menjadi milik bersama. Hal tersebut berarti bahwa komunikasi merupakan memberitahukan berita, pengetahuan, pikiran-pikiran dan nilai-nilai dengan maksud agar seseorang dapat berpartisipasi dengan tujuan agar informasi yang didapat menjadi milik bersama.

\section{KESIMPULAN}

Berdasarkan hasil penelitian dapat disimpulkan bahwa terdapat pengaruh model pembelajaran Process Oriented Guided Inquiry 
Learning (POGIL) terhadap kemampuan komunikasi siswa pada subkonsep urinaria kelas XI di MA. Kemampuan berkomunikasi tulisan siswa memperoleh nilai rata-rata sebesar 71,4 dengan kategori baik untuk kelas eksperimen dan 59,87 dengan kategori cukup untuk kelas kontrol. Kemampuan berkomunikasi lisan memperoleh nilai rata-rata sebesar 68,67 dengan kategori baik untuk kelas eksperimen dan 59,1 dengan kategori cukup untuk kelas kontrol.

\section{SARAN}

1. Penggunaan model pembelajaran Process Oriented Guided Inquiry Learning (POGIL) dapat dijadikan salah satu alternatif pembelajaran yang diterapkan di sekolah dan dapat meningkatkan kemampuan komunikasi siswa dalam proses pembelajaran dan hasil penelitian ini memberikan alternatif baru dalam pembelajaran Biologi di MA karena guru biologi di sekolah tersebut belum pernah menerapkan model pembelajaran Process Oriented Guided Inquiry Learning (POGIL).

2. Saat pembelajaran sebaiknya guru lebih memperhatikan pengelolaan kelas dalam membentuk kelompok dengan menegaskan durasi yang singkat agar alokasi waktu saat proses pembelajaran dapat berlangsung dengan baik.

3. Saat proses pembelajaran sebaiknya guru memberikan reward kepada siswa yang aktif, supaya bisa memotivasi siswa yang tidak aktif.

4. Penggunaan model Process Oriented Guided Inquiry Learning (POGIL) dalam pelaksanaannya membutuhkan waktu yang lama, diharapkan guru maupun peneliti lain dapat mengalokasikan waktu dengan baik selama proses pembelajaran, agar kegiatan belajar mengajar dapat berjalan secara efektif dan efisien.

\section{DAFTAR RUJUKAN}

Arikunto, S. 2012. Dasar-dasar Evaluasi Pendidikan Edisi 2. Jakarta: PT. Bumi Aksara.

Cholistiana, K.A. 2014. Pengaruh Model Learning Cycle 5E Terhadap Hasil Belajar Siswa pada Konsep Sistem Eksresi. Skripsi diterbitkan. Jakarta: UIN Syarif Hidayatullah.

Fujiarti, I dan Z. Mastur. 2014. Keefektifan Model POGIL Berbantuan Alat Peraga Berbasis Etnomatematika Terhadap Kemampuan Komunikasi Matematis. UJME, 3 (3): 1-7 .

Ginanjar, W.S., S. Utari \& Muslim. 2015. Penerapan Model Argument-Driven Inquiry dalam Pembelajaran IPA untuk Meningkatkan Kemampuan Argumentasi Ilmiah Siswa SMP. Pengajaran MIPA, 20 (1): 32-37. 
Hanson, D.M. 2006. Instructor's Guide to Process-Oriented Guided-Inquiry Learning, (Online) (http://repository.uinjkt.ac.i d/dspace/bitstream/123456 789/24429/1/Ika\%20Eliza $\% 20$ Cholistyana.pdf, diakses 6 Februari 2018.

Khasanah, N. 2016. SR (Science and Religion) sebagai pendekatan pembelajaran biologi pada kurikulum 2013 untuk meningkatkan karakter siswa. Biodidaktika, 11 (2). 1-9.

Kurnia, A. B dan E. Suryowati. 2014. Penerapan Realistic Mathematics Education dalam Pembelajaran Membaca Diagram Batang dan Garis Siswa SMP Kelas VII. AdMathEdu, 4 (2): 107118.

Lafenasti, Y., N. Susanti., \& D.A. Kurniawan. 2018. Analisis Hambatan Pelaksanaan Praktikum fisika Di SMA Negeri 5 Kota Jambi. 14 hlm. (Online) http://repository.unja.ac.id/3 332/1/ARTIKEL\%20FEBLI A\%20LAFENASTI\%20\%28
RSA1C313023\%29.pdf, diakses 30 Mei 2018.

Mulyasa. 2015. Guru dalam implementasi kurikulum 2013. Bandung: PT. Remaja Rosdakarya.

Ningsih, P.E., Siswoyo., I.M. Astra. Pengaruh Metode POGIL (Process Oriented Guided Inquiry Learning) Terhadap Keterampilan Proses Sains Siswa Pada Materi Suhu dan Kalor Kelas X SMA. Prosiding Seminar Nasional Fisika E-Journal, iv : 67 72.

Subali, B., D. Rusdiana., H. Firman., \& I. Kaniawati. 2015. Analisis Kemampuan Interpretasi Grafik Kinematika pada Mahasiswa Calon Fisika. (Online) http://portal.fmipa.itb.ac.id/s nips2015/files/snips_2015_b ambang_subali_09f0e76002 8d437a74c0970183b105d8.p df, diakses 5 Mei 2018.

Sumiati dan Asra. 2009. Metode Pembelajaran. Bandung: CV. Wacana Media.

Yusup, P.M. 2009. Ilmu Informasi, Komunikasi, dan Kepustakaan. Jakarta: Bumi Aksara. 